Gerasymova E.,

Grand PhD in Philosophy Sciences, Professor, National Pedagogical Drahomanov University, Kyiv, Ukraine;

Donii N.,

Grand PhD in Philosophy Sciences, Associate Professor, Academy of the State Penitentiary Service, Chernihiv, Ukraine

\title{
PHENOMENON OF PSYCHOLOGISATION EXPANDING IN MODERN SOCIAL SPACE
}

Modern social space amazes by its own diversity, eclecticism, dynamism and originality of processes that form the space through determining a new character of relationship and activity. In this frame many phenomena, well-known since ancient times or appeared recently, force the individual to build his/her own life in a new way and to hierarchize own aspirations. Among causes that constantly make the individual adjust to social space requirements should be mentioned psychologisation, the tendency to enhance space of psychological knowledge effect and to wind it into the design of daily occurrence.

Objective of the study is to present the results of reflection of psychological study development during the 20th and the 21th centuries as the process that allowed talking about social space as the territory of psychology planning. The method is - analyzing the genesis and demonstration of psychologisation as a process.

It has been pointed out that Psychology proclaimed the individual as a prime cause, the domination of psychoanalytic position «life as a thing in itself» removed social factor from the circle of paramount importance in this problem solving. No wonder, it provoked the fact that psychological practice was not able to reduce alienation and even more its expansion was enhancing the distance between the individual and social space and indirectly affected alienation and disintegration growth. It has been stated that psychologists who are trying to cure the individual, on the contrary, further enhance those qualities that arise the problem of the desire to be atomized and alien. In addition to alienation, the consistent psychologisation of social space caused the experience of troubles as a personal problem and formed adjustment for the probability of its solution in non-social ways, which legitimized loneliness, despair and anxiety in individuals' lives. It has been concluded that psychologisation cannot be read uniquely as a positive moment. Positivy is that psychologisation provides individuals more efficient tools to self-knowledge and life-cognition in social space, but negativity is that the magnitude of the penetration of Psychology indirectly led to social disintegration, and social space instead of a mentally healthy and socially active person received the growth in the number of mental illnesses and sensitively incompetent individuals. The importance of psychologisation expansion bounding has been emphasized.

Key words: social space, Psychology, psychologisation, emptiness, alienation, indifference. 
Urgency of the research. Modern social space amazes by its own diversity, eclecticism, dynamism and originality of processes that form it and its space through determining a new character of relationships and activity. In this frame many phenomena either being well-known since ancient times or appeared recently, force the individual to build his/her own life in a new way and to hierarchize own aspirations. Among causes that constantly make the individual adjust to social space requirements it should be mentioned psychologisation, the tendency to enhance space of psychological knowledge effect and to wind it into the design of daily occurrence.

Objective of the study is to present the results of reflection of psychological study development during the $20^{\text {th }}$ and the $21^{\text {st }}$ centuries as the process that allowed talking about social space as the territory of psychology planning.

Analysis of recent researches and publications. In general, the scale of the onset of psychologisation is impressive. So, with the small size of academic university science, which it was in the middle of the $19^{\text {th }}$ century, psychology turned into a huge scientific and practical sphere of activity that occupied a dominant position in the social space of the $20^{\text {th }}$ century. At the beginning of the $21^{\text {st }}$ century psychology has become a sphere that gave an explanation to a person about his/her actions, managed his/her decisions, advised on those issues that had never been voiced aloud. Such courage was invoked by science for the object of research, because it «was more interested in the individual himself, as he is conscious of himself, builds personal history and how, due to him, he constitutes himself» [1, p. 207].

For the first time the mankind came across psychologisation, and namely the thought of the self, in the work «An Essay Concerning Human Understanding» written by John Locke in 1689 [2]. However, the turning point why psychologisation appeared among other crucial issues was the expansion of economocentrism and the growth of the number of questions how to avoid conflicts in solving problems occurring while individuals interacting within social space. It happened somewhere in the period between 50's and 80-90's of the $20^{\text {th }}$ century.

The most powerfully the problem of psychologisation is presented in studies of Western European and American science. 
Thus, such researchers as K.J. Gergen, K. Danziger, P. van Drunen, K. Lesh, G. Richards, N. Rose, R. Sennet, R. Smith, S. Word, J Janša and others were indirectly involved in the discussion of this problem. In general, the publications of Western researchers devoted to psychologisation can be divided into different alliances. Apart from others there are works of P. Foucault followers, namely R. Castel, P. Castel, A. Lovell, who focused on approving the fact that most knowledge is regressive due to indifference to traditions, but the most sincere and authentic knowledge is the tool to control the society [3]. The powerful alliance of publications devoted to psychologisation, is presented by French researchers who focus on revealing the phenomenon in the field of professional and productive relations. For instance, M. Loriol, V. Boussard, S. Caroly talk about the resistance to psychologisation of working relations, St. Morel conducts an analysis on psychologisation of working relations in the field of providing giving care services and draws attention to the relevance of approach to the problems of patients on psychological level. Another alliance is presented by publications that study the impact of psychologisation on the Western culture. For instant, Gr.Eghigian, a follower of John Locke, studies psychologisation of the self in the frame of social Germany of 1945-1975 [4], and a Norwegian researcher Ole Jacob Madsen reflects on the advancement of the psychologisation of Western society through the notion of «the therapeutic ethos» [5]. The other publications belong to the alliance which representatives consider that psychology has conquered spaces vested to religion [6]. Thus, Julia Yost, a representative of English at Yale University, study «psychologisation of everything» from the position of the balance between religion and deviation from generally recognized behaviour [7]. Judith M. Stillion and Thomas Attig [8] in their research perform a detailed analysis on psychologisation of grief. A separate place takes the work «Psychologisation and the Subject of Late Modernity» written by a Belgian researcher Jan De Vos [9], where he presents Psychology as a Post-Cartesian Discipline and tells about the appearance of a new type of a human - Homo Psychologicus.

Currently the issue of revealing the position of psychologisation within modern social space is studied in researches of Russian 
scientists, namely A. F. Bondarenko, N. I. Koniukhov, A. M. Seriohin, I. Ye. Syrotkina, A. V. Yurievych. However, it should be mentioned that in domestic scientific thought the issue of psychologisation expansion in social space has rarely become a subject of research.

Presentation of the main material of the study. After the studies of Modern of the middle of the $20^{\text {th }}$ century modern scholars state that the development of the Modern project has led to a significant change in the position of the main characters of the world, namely: «God loses His place, and along with him a man loses Him too» [10, p. 261], and completely changed the system of value reference. In particular, M. Weber wrote: «The fate of our times is characterized by rationalisation and intellectualisation and, above all, by the disenchantment of the world; precisely the ultimate and most sublime values have retreated from public life» [11, p. 726]. Thus in that world Reason took a dominant place and, as Romano Guardini states, it determined one more transformation: «a man began to live out the world and himself in that world in a new way. A man was irresistibly assured that at least the Present had just begun and the previous life had been the prerequisite, preparation or an obstacle. A man of the Modern time has faced the reality and all sources of a Being will have to come out. The energy of a puzzled out nature will merge with human energy and everything will get a life» $[10, \mathrm{p}$. 269]. The ultimate total of Reason entrance upon the forestage in value hierarchy has become the transformation of the temporal world into the endlessly diverse one and a man is gradually realizing his own importance and the self like new criteria of value of human life.

The anthropological turn that took place in the history has determined the restructuring of the pyramid of sciences, which were engaged in human studies, and natural sciences. The retreat from sole biological knowledge in studying and a human self-disclosure, as well as psychology consolidation, required reasoning the difference between natural sciences and humanities. The first, who tried to differentiate them from the modern position, was Wilhelm Dilthey. He insisted on the fact that natural sciences dealt with explanation that opposed to humanities, which focused on comprehension. Such an understanding is achieved by a special method of humanities, the 
method of comprehension that allows seeing a point in whole, but not to be reaching it through long-term experiments. So, «man as a fact prior to history and society», - wrote Dilthey, - «is a fiction of genetic explanation; the man whom sound analytical science has for its object is the individual as an element in society. A difficult problem, which is called to solve Psychology, is in analytical knowledge of the general traits of the person» [12, p. 206].

Dilthey's stand was supported by Karl Jaspers. Taking into consideration the weighty leading position of the two mentioned philosophers in scientific circles at that time, it should be stated that actually philosophy of life became the trend, which grounded a more distinct look at a man than that had been before the emergence of psychology. Moreover, actually they built a «bridge» between Psychology and Sociology and grounded the fact that Psychology was spreading within scientific sphere of Sociology. Thus, Psychology and Sociology, choosing objects for scientific research, must interact.

So, Dilthey suggested that the individual is not an autonomous personality, because he is involved in social life and sciences, engaged in studying a human and society, must come into an inseverable contact. The individual is not independent. He is engaged in a certain social order. Either vital or historical context are tremendously tempted to absorb the individual, to dissolve him in social relations. Of course, society as a social phenomenon is a reliable criterion of the diversity and effectiveness of public relations. However, the individual resists public dictation. So there is another phenomenon - atomisation of society. And here is a dilemma concerning simultaneous individualization and atomisation. The dilemma, in the opinion of Michel Foucault, was managed to be resolved by Sigmund Freud through conducting psychoanalysis $[1, \mathrm{p}$. 215]. And with other trends of Psychology, that appeared later, psychoanalysis was considered as panacea from social problems and diseases. Then, since $40-50$ 's of the $20^{\text {th }}$ century Psychology was recreated into a form of empirical and existential analysis, which is able to explain a human's reality, its temporal-spatial, dynamic, sense and project characteristics.

And here is a problem, which has not been resolved till today, came up. Having rewarded a person with a strong need in an 
individual sense and a constant dynamic life, social space at the same time deprived of its internal incentives for finding meaning, differentiated from independent production, and developed dependence on its external supply. Changes in the worldview led to changes in goal-setting: the person began to set goals and, thanks to the ideology of mass-cult spreading, almost instantly began to achieve them. Under the scenario stand-by time of needs satisfaction also reduced: needs turn up, later they are satisfied and new needs appear again. The speed of meeting the needs and satisfying the desired determines the need for a constant set of new goals. As a result, such acceleration led to the emergence of the phenomenon of «need for need», and permanent circulation of «meta-achievementgoal», in turn, determined the deployment in the social space of boredom and its transformation into an existential-moral problem.

All mentioned above transformations were resulted in the following: for an ordinary person the problem of choice was transformed into daily one, and slow atomisation of social life changed, becoming a witness of destruction of the traditional order. Changes of positions turned the searching for a sense of life vector direction and redirected life energy: from the passive expectation of instructions, the individual proceeded to active actions in searching of himself, the meaning of his life and almost ceased to rely on the other. As a result, it either magnified the individual's position or weakened social space.

Gradually, a man, lonely wandering with social labyrinths, was alone with himself and began to express his intention of liberation from himself. The individual also started suffering from an inferiority complex and felt discomfort due to the feelings of specific emptiness: «from now on we are ruled by emptiness, but such emptiness, which is neither tragic nor apocalyptic» [13, p. 24]. Quite quickly, emptiness was conquered by new suppliers of traditions, because, as you know, the holy place is not empty. So, emptiness that had been formed after God's death and loss of the Other was chaotically filled up with a new sense by ideologists not caring of a new sense's quality and value. Precisely Psychology, which strengthened in concept, methodologically and instrumentally, became such a phenomenon that began to fill emptiness upon. 
So, it should be stated that the popularization of psychological practices peaked in the 60 's of the $20^{\text {th }}$ century after another aggravation of the crisis of world outlook. Psychology at that stage of mankind's evolution, having passed some stages of selfdevelopment, began more frequently to propagandize self-help under the control of specialists. Thus, having replaced religion psychology unsuccessfully tried to fill upon emptiness and supported preservation of the deformed world. It could happen because psychology is the top of rationalisation and intellectualisation; therefore, the irrational soul was left without a «doctor» because the clergyman and psychologist are physicians of different tools and level of professionalism, so, the result of their treatment is different.

Psychology proclaimed the individual the prime cause, and the domination of psychoanalytic position «life as a thing in itself» removed social factor from the circle of paramount importance in this problem solving. No wonder, it affected the fact that psychological practice was not able to reduce alienation and even more its expansion was enhancing the distance between the individual and social space/the Other. It is no coincidence that some American experts (J. Zerzan, Ph. Cushman, F. Rustan, N. Simpson, O. Toffler and others) are assured that psychoanalysis and psychotherapists caused the growth of alienation, disintegration and increasing suicide rate in the American society. Scientists emphasize that psychologists, trying to cure the individual, on the contrary strengthened the characteristics which generate the problem of aspiration for alienation and atomisation.

The nature of the relationship between the psychologist/psychotherapist and the client is believed to promote this aspiration. These relationships as a rule are one-way trust: the client talks about himself and his troubles, and a psychotherapist by every possible means tries to avoid a social and emotional contact. In the alliance of «psychotherapist/client» there is no emotional and sensitive bound like friendship. Here we are talking about the depersonalization of partners and the formation of individuals to the role of objects, things that are used for profits.

The abnormality of such relationships is testified by the fact that the psychologist / psychotherapist is experiencing something like a 
split, namely, he clearly delineates the line between soul and mind, where during the session the client exploits the mind, and the irrational component remains beyond the scope of interaction. Thus, in this interaction there is the ignoring the moment presented by Aristotle's theory of soul, «the human soul is everything», which makes the soul remain unaffected and alone with its emptiness. Such a system of relations testifies marginalization or something that can be characterized as «indifference».

Apart from indifference/alienation consecutive psychologisation of social space caused the experience of troubles as a personal problem and formed the setting of probability to solve the problem by unsociable means; it led to legitimation of loneliness, despair and anxiety in the life of the individual. As a result, the individual came across one more paradox: expending psychologisation generated social enslavement as well as objection of «social» where the society had to be responsible for imposed living conditions for the individual. Indicative in this context are the innovations by $\mathrm{M}$. Seligman, who is famous for the description of such phenomena as «syndrome of learned helplessness» and «conscious optimism». The American researcher noted with sadness that the depreciation of religion and the loss of socially useful functions by the family, coupled with the growth of individualistic settings such as «you can do it», generate hopelessness and self-excuse - «This is your fault, since you did nothing».

Conclusions and perspectives of recent researches. It should be stated that psychologisation carries in itself either a positive component for the individual and social space or a negative one. Positivity is that psychologisation provided individuals more efficient tools to self-knowledge and life-cognition in social space, but negativity is that the magnitude of the penetration of Psychology indirectly led to social disintegration and social space, instead of a mentally healthy and a socially active person, received the growth in the number of mental illnesses and sensitively incompetent individuals. As aforesaid, it needs a scrutiny of spreading psychological knowledge and perhaps performing some measures in order to restrict presentations of psychological tools in a nonspecialized source base. 


\section{References}

1. Foucault, P., "Psychology from 1850 to 1950", Early work, Vladimir Dal', St. Petersburg, pp. 197-240.

2. Locke, Dz. (1985), Sochineniya [WorksVol. 1-3], Mysl, Moscow, T. 1.

3. Castel, R., Castel, F. and Lovell, A. M. (1982), The psychiatric society, Columbia University Press, New York.

4. Eghigian, G. (2004), "The Psychologisation of the Socialist Self: East German Forensic Psychology and its Deviants, 1945-1975", German History, Vol. 22, T. 2, pp. 181-205.

5. Madsen, O. J. (2014), "Psychologisation and Critique in Modernday Western culture", Soc. and Pers. Psychol. Compass, Vol. 8, T. 5, pp. 193-200.

6. Juneman, A. and Any, R. (2014), “Theologization" of Psychology and "Psychologization" of Religion: How Do Psychology and Religion Supposedly Contribute to Prevent and Overcome Social Conflicts?", Procedia Environmental Sciences, No. 20, pp. 516-525, aveliable at: https://doi.org/10.1016/j.proenv.2014.03.064.

7. Yost, J. (2015), "The psychologisation of everything", First Things: America's most influential journal of religion and public life, available at: https://www.firstthings.com/web-exclusives/2015/06/the-psychologizationof-everything.

8. Stillion, J. M. and Attig, T. (2015), Death, Dying, and Bereavement: Contemporary Perspectives, Institutions, and Practices, Springer Publishing Company, New York.

9. De Vos, J. (2013), Psychologization and the Subject of Late Modernity, Palgrave Macmillan, London, New York.

10. Guardini, R. (1993), "The end of the modern philosophy", The phenomenon of a man: anthology, Vysshaya shkola, Moscow, pp. 240-296.

11. Weber, M. (1990), Science as a vocation and as a profession, Selected works, Progress, Moscow, pp. 707-735.

12. Diltey, W. (2000), Printsipy metodologii gumanitarnykh nauk, Sobraniye sochineniy, Dom intellektual'noy knigi, Moscow, Vol. 1-6, T. 1, pp. 93-231.

13. Lipovetski, Z.H. (2001), The era of emptiness: Essays on contemporary individualism, Vladimir Dal', St. Petersburg. 
Герасимова Е. М., доктор філософських наук, професор, Національний педагогічний університет імені М. П. Драгоманова, м. Київ, Україна; Доній Н. С.,

доктор філософських наук, професор, Академія Державної пенітенціарної служби, м. Чернігів, Україна ФЕНОМЕН ПОШИРЕННЯ ПСИХОЛОГІї
В СОЦІАЛЬНОМУ ПРОСТОРІ НОВІТНЬОГО ЧАСУ

Сучасний сочіальний простір вражає еклектизмом, динамізмом і нестандартністю прочесів, щуо формують його і його межі, детермінуючи при ц̧ьому також новий характер відносин і діяльності. До причин, які підштовхують людину постійно підлаштовуватися під вимоги соціального простору, належить психологізації - тенденція до розширення простору впливу психологічного знання та вплетіння його в канву повсякдення.

Метою є представлення результатів рефлексї щодо розгортання психологічних учень протягом $X X-X X I \mathrm{~cm}$. як прочесу, щцо дозволив вести мову про новітній сочіальний простір як територію панування психологї̈.

Вказано, щзо психологія проголосила індивіда першорядною проблемою, а домінування психоаналітичної позиції «життя як річ-у-собі», вивела соціальний фактор з кола впливових щуодо вирімення цієї проблеми. Це вплинуло на те, щуо, як не дивно, але психологічна практика виявилася не здатною зменшити відчуженість, й, навіть більше того, ї̈ розгортання збільшувало відстань між індивідом і сочіальним простором/іншим й опосередковано впливало на зростання відчуження та дезінтеграчії. Засвідчено, що психологи, намагаючись вилікувати індивіда, навпаки, ще більше посилюють ті якості, які й породжують проблему прагнення до атомізачії й аліенації. Крім відчуження, послідовна психологізачія сочіального простору спричинила переживання негараздів як особистої проблеми й сформувала установку ймовірності ї̈ вирішення несоціальними способами, чим легітимізувала самотність, відчай та занепокоєння в житті індивідів.

Зроблено висновок, щуо психологізаџію не можна трактувати як однозначно позитивний прочес. Позитивність полягає в тому, щзо психологізація надала людині більш дієві інструменти щзодо самопізнання та пізнання життя в сочіальному просторі, а негативність - у тому, щзо масштабність проникнення психології опосередковано спричинила соціальну дезінтеграцію, а сочіум замість психічно здорової та сочіально активної людини отримав збільшення кількості психічни захворювань і сенситивно неспроможних індивідів. Представлено думку щңодо доцільності встановлення меж поширення психологічних знань.

Ключові слова: сочіальний простір, психологія, психологізачія, порожнеча, байдужість. 